Vol. 40(2), pp. 82-96, Dec. 2021

ISSN 1821-536X (print)

ISSN 2619-8789 (electronic)
Tanzania Journal of Engineering and Technology

Copyright (C) 2021 College of Engineering and

Technology, University of Dar es Salaam

Full Length Research Paper

\title{
Effects of Constructed Wetlands Plants on Phosphorus Removal from Domestic Wastewater in Gaborone, Botswana
}

\author{
Baboloki Autlwetse $^{1}$ and Richard Joseph Kimwaga ${ }^{2 *}$ \\ ${ }^{1}$ The Permanent Okavango River Basin Commission (OKACOM), P. O. Box 46082, Gaborone, \\ Botswana \\ ${ }^{2}$ University of Dar es Salaam, Water Resources Engineering Department, P. O. Box 35131, Dar es \\ Salaam \\ *Email of corresponding author: rkimwaga2007@yahoo.com, or rjkimwaga@udsm.ac.tz
}

\begin{abstract}
The United Nations, Sustainable Development Goal (SDG) Target 6.3. aims at "halving the proportion of untreated waste water and substantially increasing recycling and safe reuse globally" by 2030. To achieve this target, sustainable and context-specific wastewater treatment systems are urgently needed. Constructed wetlands $(C W)$ is one of the wastewater treatment technological options available. $\mathrm{CW}$ have been widely accepted and acknowledged as simple, low cost, alternative and appropriate domestic wastewater treatment technology. $C W$ were piloted by the Department of Water Affairs, Gaborone, Botswana to assess their treatment performance. Specifically, the study investigated the effects of $C W$ plants on Phosphorus $(P)$ removal from domestic wastewater. The first $C W$ cell (CA) was a control which was filled with sand only, the second cell (CB) was planted with Typha Latifolia, the third (CC) with Cyperus Papyrus and the fourth (CD) with Phragmites Mauritianus. Each cell had a surface area of $100 \mathrm{~m}^{2}$ and received a wastewater discharge of $4 \mathrm{~m}^{3} /$ day. River sand with porosity of 0.44 and particle size diameter ranging from 2-7mm was used as plants growing media. Wastewater samples were analysed in accordance with Standard Methods for Examination of Water and Wastewater. The results showed that the P treatment performance efficiencies for $C A, C B, C C$, and $C D$ were $93.6 \%, 97.4 \%, 98.1 \%$ and $98.4 \%$ respectively. Despite that there was $C W$ plants contribution towards $P$ removal from domestic wastewater, there was however no statistically significant performance difference $(p>0.05)$ in $P$ removal between the $C W$ cells planted with different plant species. The mean effluent $P$ concentrations from the different $C W$ cells were; $C A 0.62 \mathrm{mg} / \mathrm{l}, C B 0.28 \mathrm{mg} / \mathrm{l}, C C 0.19 \mathrm{mg} / \mathrm{l}$ and $C D 0.16 \mathrm{mg} / \mathrm{l}$. Thus, the mean P concentration from the effluent of $\mathrm{Cl}$ was above the Botswana Bureau of Standards Limits of 0.5mg/l. Hence the effluent was non-compliant with Botswana standards for the discharge of effluent into the environment.
\end{abstract}

Key words: Plants effects, performance, phosphorus removal, type of plant, no statistically significance difference, constructed wetlands.

\section{INTRODUCTION}

\section{Global Development Agenda and Wastewater}

The United Nations (UN), Sustainable Development Goal (SGD) Target 6.3 is about water quality and wastewater (UN, 2015). The target aspires, by 2030, to reduce by halving the proportion of untreated wastewater and substantially increasing recycling and safe reuse globally (UN, 2015). Target 6.3 seeks to improve ambient water quality by eliminating, minimizing and significantly reducing different pollution streams into 
water bodies (UN, 2015). The main sources of water quality pollution is point sources emanating from households, commercial establishments and industries. Also, the pollution comes originates from non-point source from urban and agricultural land run-off (UN, 2015).

Households wastewater can contribute to the wide spread of pathogens and detrimental nutrient loadings in receiving waters if it is inadequately and inappropriately managed (Comber et al., 2013). On the other hand, wastewater originating from economic activities such as manufacturing industries may contain a variety of pollutants, including hazardous substances. One of the wastewater contaminants that contributes to nutrient loadings in receiving waters is Phosphorus (Comber et al., 2013).

Phosphorus, $\mathrm{P}$, is an essential and yet a limiting nutrient that significantly contributes to the undesirable growth of algae due to the eutrophication of water bodies (Allan 2004; Oliveira and Machado, 2013). P effects in drinking water have been documented to have little or no human health effect (Makris et al., 2014). P pathways to water bodies can be either from sewage or from agricultural runoff containing fertilizers and animal wastes (Dodds and Smith, 2016). In the past, Phosphate, $\mathrm{PO}_{4}{ }^{3-}$, the inorganic form of phosphorus, has been commonly used in detergents (Fisher et al., 1995; Sterner, 2008). Despite their ban, phosphate-based detergents, have been reported to threaten the environmental health integrity (Howarth and Paerl, 2008; Lewis and Wurtsbaugh, 2008; Pearl, 2009; Comber et al.,2013)

Thus, wastewater management solutions should be devised to manage the water pollution and its consequent eutrophication. $\mathrm{P}$ pathways to water body are through the inflows including wastewater discharge, precipitation and atmospheric deposition and the release from the water bottom sediments. P removal includes sedimentation the outflow (Dodds and
Smith, 2016). Since P is a limiting nutrient, its control will generally result in a substantial algal biomass reduction as compared with the corresponding amount of nitrogen (Dodds and Welch, 2000). Hence, if the wastewater treatment objective is $\mathrm{P}$ removal, then there will be less algal bloom in the water body since reduction in $\mathrm{P}$ results in greater reduction of algal bloom (Dodds and Welch, 2000). If nitrogen input reduction strategy is implemented without proportional $\mathrm{P}$ reduction, it will develop a low N/P ratio which favours nitrogen fixing nuisance algae. Hence, there will be no reduction in algal biomass (Dodds and Welch, 2000).

Globally, wastewater management is increasingly becoming the issue of major environmental management concern (Scott et al., 2004). Recently, adequate, appropriate and sustainable wastewater treatment has received great attention so as to control pollution of the available freshwater systems (Scott and Liqa Raschid-Sally, 2012). Also to achieve UN SDG target 6.3 (UN, 2015). Broadly, the available wastewater treatment technologies can be categorized as either on-site or off-site treatment facilities. Due to improved water supply services coupled with human development, there is now more push towards water connected households throughout the world (Scott and Liqa Raschid-Sally, 2012). This has led to the construction of large-scale off-site technologies (conventional and biological systems) (Scott and Liqa Raschid-Sally, 2012). These technologies are used to treat wastewater from diverse places at a larger scale. However, conventional wastewater treatment systems have been observed to have shortcomings, especially for poor and low-income settlements. These shortcomings include high investment and operation and maintenance costs. Consequently, alternative and costeffective wastewater treatment solutions and approaches have to be introduced. Constructed Wetlands for wastewater treatment, has been widely accepted and 
used as alternative to the conventional wastewater treatment technologies under particular circumstances and context (Brix, 1997; Vyamazal et al., 1998). Recently, $\mathrm{CW}$ are implemented as nature-based solutions (Haddis et al., 2020).

CWs technology for wastewater treatment has been used to treat different types of wastewater. Yet, different CWs components have been extensively studied (Kadlec and Knight, 1996; Vymazalet al, 1998; Sundaravadivel and Vigneswaran, 2001; Senzia et al., 2003; Kimwagaet al., 2004). CWs are increasingly recognized as alternative and green technology, that can be employed to treat domestic wastewater (Crites et al.,1997; Obarska-Pempkowiak and Klimkowska, 1999; Babatunde et al.,2008; Langergraberet al., 2008). Studies conducted in tropical climate have provided promising CWs performance results (Senzia et al., 2003; Kimwagaet al.,2004, Mayo and Bigambo, 2005). Pollutants treatment mechanisms and processes taking place in the CWs have been studied (Kadlec and Knight, 1996; Vymazal et al, 1998, Sundaravadivel and Vigneswaran; 2001, Senziaet al., 2003; Kimwaga et al., 2004, Mayo and Bigambo, 2005). The wastewater pollutants that have been studied include but not limited to carbon, nitrogen and phosphorus, dissolved oxygen (DO), Biochemical Oxygen Demand (BOD), Chemical Oxygen Demand (COD) and Total Suspended Solids (TSS). (Kadlec and Knight, 1996; Vymazal et al, 1998; Van der Peijl and Verhoeven,1999; Sundaravadivel and Vigneswaran2001; Kimwaga et al., 2004).

\section{Constructed Wetlands in Gaborone, Botswana}

In Botswana, few CWs have been introduced for domestic wastewater treatment. Studies conducted elsewhere have suggested CWs to be low cost technologies in terms of both investments and operation and maintenance (Kadlec and Knight, 1996; Vymazalet al, 1998; Sundaravadivel and Vigneswaran, 2001;
Senziaet al., 2003; Kimwaga et al., 2004). In Botswana, CWs were introduced and are being implemented to treat wastewater at institutional levels. It is important that once a treatment facility is constructed, its performance be monitored. The objective of monitoring is to track the treatment performance compliance. This way, it will help to rectify any malfunctioning part of the facility.

In an effort to implement this concept and approach, the Department of Water Affairs (DWA) of Botswana piloted CWs to treat its wastewater, to demonstrate the treatment feasibility of this low-cost wastewater treatment technology. All the generated wastewater from the DWA offices is directed and connected to a septic tank as a pre-treatment unit. From there, it flows into four CWs for further treatment. This study was conducted with the main objective of assessing the treatment feasibility and performance of the four CWs for the $\mathrm{P}$ removal from domestic wastewater. Specifically, the study was undertaken to investigate the effects of $\mathrm{CW}$ plants on $\mathrm{P}$ removal from domestic wastewater. The results were expected to guide the selection of the appropriate $\mathrm{CW}$ plants to be used in the Botswana context. The larger proportion of the generated wastewater was domestic origin. Small proportion was industrial wastewater originating from washing machinery in mechanical workshops using chemicals which are likely to contain phosphates. Since no information was available and documented on the treatment performance of the DWA CWs, it was imperative to undertake such a study. The adsorption capacity of the river sand used in the DWA CWs and the best plants that should be used in other new $\mathrm{CWs}$ in Botswana were investigated. It is in this work that this information could be generated and used to advise wastewater generators on the use of $\mathrm{CWs}$ for wastewater treatment.

CWs at DWA are of the horizontal subsurface flow system (HSSFS) type. As part of water demand management 
strategies, treated wastewater from CWs effluent is recycled and reusedfor irrigating the vegetable garden, the orchard and the lawns that are within the offices compound. This has raised some eye brows of some employees and customers of DWA, about the quality of the treated effluent. This is particularly so, when they are to buy the vegetables irrigated with the treated wastewater. Thus, the study was conducted to assess the CWs treatment performance.

\section{MATERIALS AND METHODS}

\section{Description of Study Area}

The CWs case study was in Gaborone, Botswana located in the premises of the Department of Water Affairs. The CWs in DWA started to operate in the late 2004. They treat wastewater generated by about 1000 employees. The activities that contribute to wastewater generation include; using the offices, restrooms, cleaning the floors and washing the machinery. Generated wastewater is collected and directed into a septic tank as pre-treatment, from which the wastewater flows into four treatment cells. Each cell was designed and operated with a discharge rate of $4 \mathrm{~m}^{3} /$ day. Wastewater hydraulic retention time (HRT) was estimated to be 5 days.

\section{Design and Operation of Constructed Wetland Cells}

The design parameter for the DWA CW was based on the acceptable effluent quality of $\mathrm{BOD}_{5}$ of $30 \mathrm{mg} / 1$ in accordance with World Health Organization and Botswana Bureau of Standards (BOS 93:2005). The influent design $\mathrm{BOD}_{5}$ was obtained from the effluent characteristics of the septic tank. The CW was designed using a plug flow regime approach. The following equation was used to size the $\mathrm{CW}$.

$$
A_{s}=L W=\frac{Q\left(\ln c_{o}-\ln c_{e}\right)}{K_{T} D \eta}
$$

where; $A_{s}=$ surface area $\left(\mathrm{m}^{2}\right)$ of subsurface flow $\mathrm{CW}$ required, $L=$ length of $\mathrm{CW}$, meter, $\mathrm{W}=$ width of the $\mathrm{CW}$, meter, $\mathrm{Q}=$ average flow rate, $\mathrm{m}^{3}$. day ${ }^{-1}, \mathrm{Co}=$ average influent BOD concentration, mg. $\mathrm{L}^{-1}, \mathrm{Ce}=$ average design effluent BOD concentration, mg. $\mathrm{L}^{-1}, k \mathrm{~T}=$ temperature dependent first-order reaction rate constant, day $^{-1}, \mathrm{D}=$ depth of water column, meter and $\eta=$ porosity of the substrate medium (percentage expressed as fraction).

Thus, the dimensions of each CW cell were found to be: length, $\mathrm{L}=25 \mathrm{~m}$, width, $\mathrm{W}=$ $4 \mathrm{~m}$, media depth, $\mathrm{d}=0.6 \mathrm{~m}$ and a free board of $0.15 \mathrm{~m}$. The surface area, $\mathrm{A}_{\mathrm{s}}$, was thus $100 \mathrm{~m}^{2}$ and the substrate effective volume, $\mathrm{V}=60 \mathrm{~m}^{3}$. Sand which was obtained from river had a varying sizes ranging from 2$7 \mathrm{~mm}$ was used as plants growing media. The river sand had porosity, $\mathrm{n}=0.44$ and HRT, $t=5$ days. The bottom of the cells was constructed with a slope of $1 \%$, to help in wastewater flow through the system by gravity from the inlet to the outlet as recommended by (Vymazal et al., 1998, Sundaravadivel and Vigneswaran 2001). Figure 1 shows the sketch drawings of the CW cell plan and cross section.

At the inlet and outlet of each CW cells, gravel media of sizes ranging from $8-25 \mathrm{~mm}$ were used, to evenly distribute wastewater across the whole width of the cell. The cells were configured in parallel arrangement to each other as shown in Figure 2. Three cells were each filled by sand and planted by three different plants species (Phragmites Mauritianus, Typha Latifolia and Cyperus Papyrus). Their selection was based on the documented good P removal efficiencies, local availability and high productivity rate in terms of P update (Kadlec and Wallace 2009). 


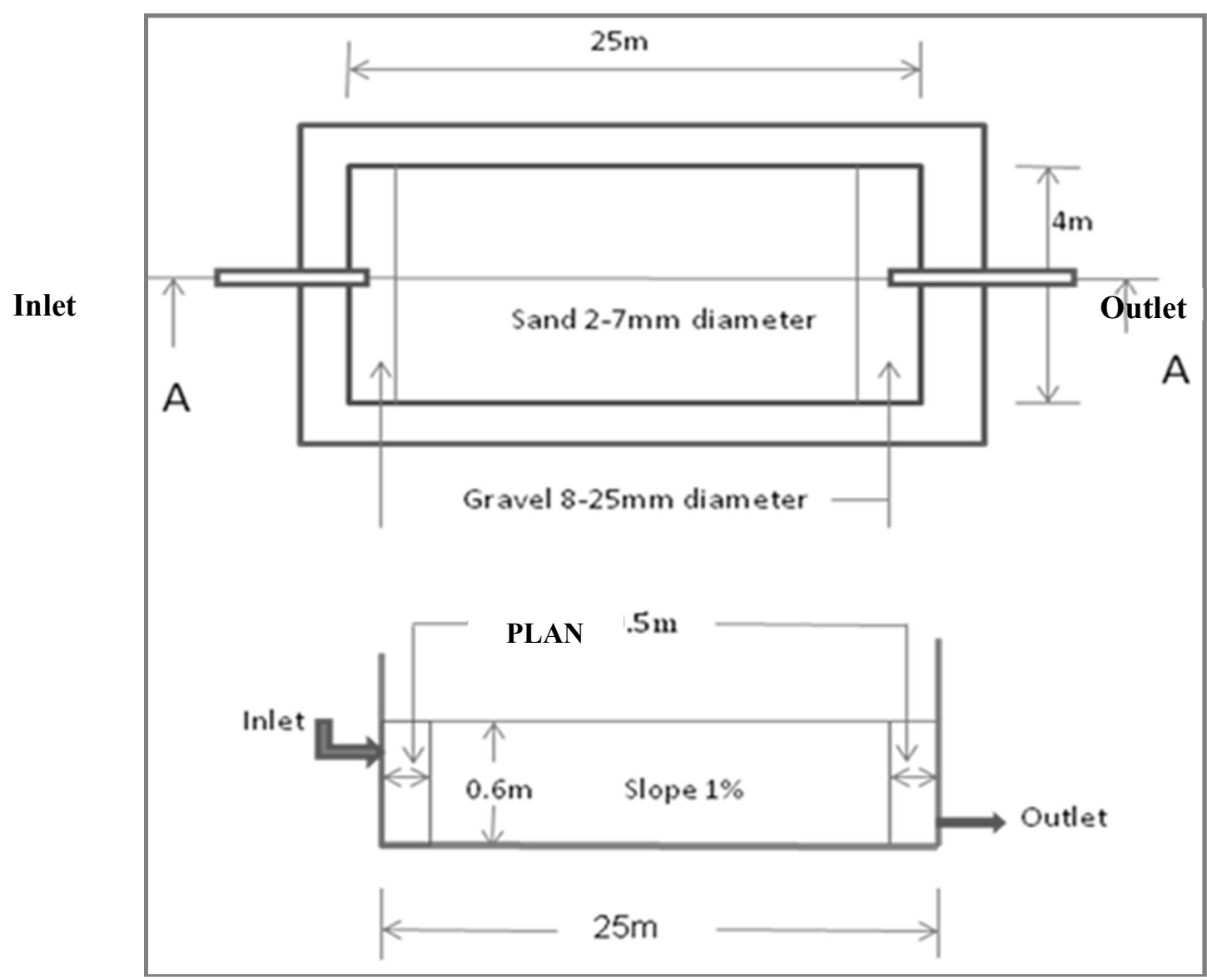

CROSS SECTION A-A

Figure 1: Sketch drawings of $\mathrm{CW}$ cell plan and cross section

Also, the plants selection criteria for use in CW wastewater treatment systems are those reported by Tanner, 1996 which include: a) ecological acceptability, that is, no significant weed or disease risks or danger to the ecological or genetic integrity of surrounding natural ecosystems, b) tolerance of local climatic conditions, pests and diseases, c) tolerance of pollutants and hypertrophic water-logged conditions, d) ready propagation, and rapid establishment, spread and growth; and e) high pollutant removal capacity, either through direct assimilation or storage, or indirectly by enhancement of microbial transformations. The last cell was set as a control, meaning that it was not planted and thus it had sand only. A two-compartment septic tank was also designed and constructed. The tank was $60 \mathrm{~m}^{3}$ in volume and had an estimated HRT of 3 days. Raw sewage from the ablutions and wastewater generated by cleaning the floors, was first collected into the septic tank, before discharging it into the CWs. Hence, the septic tank acted as pre-treatment for the CWs.

\section{Wastewater Sampling Procedures}

Wastewater samples were collected at the inlets and outlets of the CW cells as shown in Figure 2. Samples were also collected within the CWs at distances of $5 \mathrm{~m}, 10 \mathrm{~m}$, $15 \mathrm{~m}$ and $20 \mathrm{~m}$ from the inlets. Sampling points were located within each cell. This was done to determine the variation of phosphorus removal along the cell lengths. $\mathrm{pH}$, Temperature and DO were determined in-situ while Phosphorus was analysed in the laboratory. The sampling duration was six months from December 2007 to May 2008. The sampling frequency was once per week. Wastewater were sampled during 
day time. A total of 25 water samples were analysed. The wastewater samples for phosphorus were filtered through a Whatman $0.45 \mu \mathrm{m}$ filter paper and analysed using the IC machine. All wastewater samples were analysed according to the Standard Methods for the Examination of Water and Wastewater (APHA, 2000).

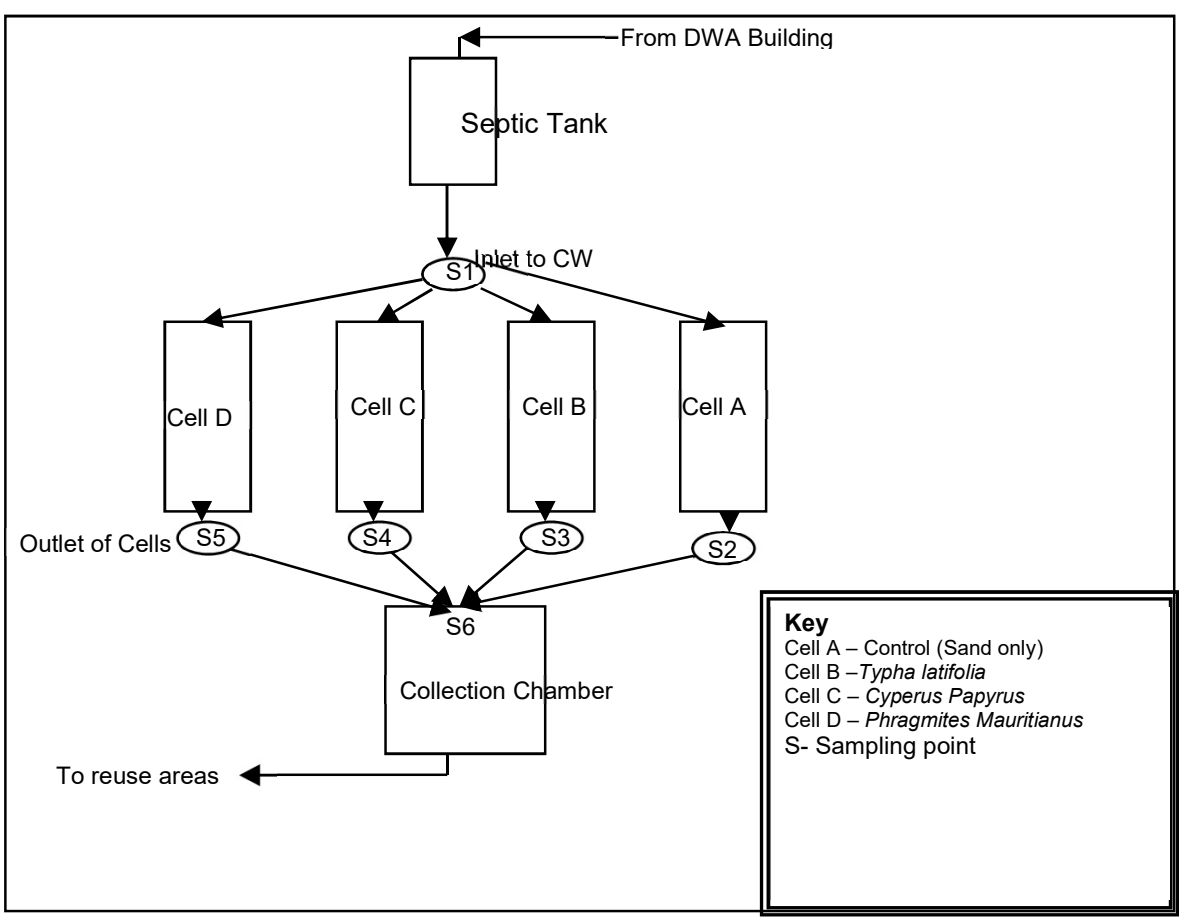

Figure 2: Sampling Points for Wastewater Analysis

\section{River Sand Sampling Procedures}

Sand samples were collected from within each cell in clear clean plastics, and taken to the soil laboratory for sand porosity and particle size ranges analysis. Samples were collected at a distance of $5 \mathrm{~m}, 10,15 \mathrm{~m}$, and $20 \mathrm{~m}$ from the inlet point within each cell. Figure 3 shows the sampling points along a cell.

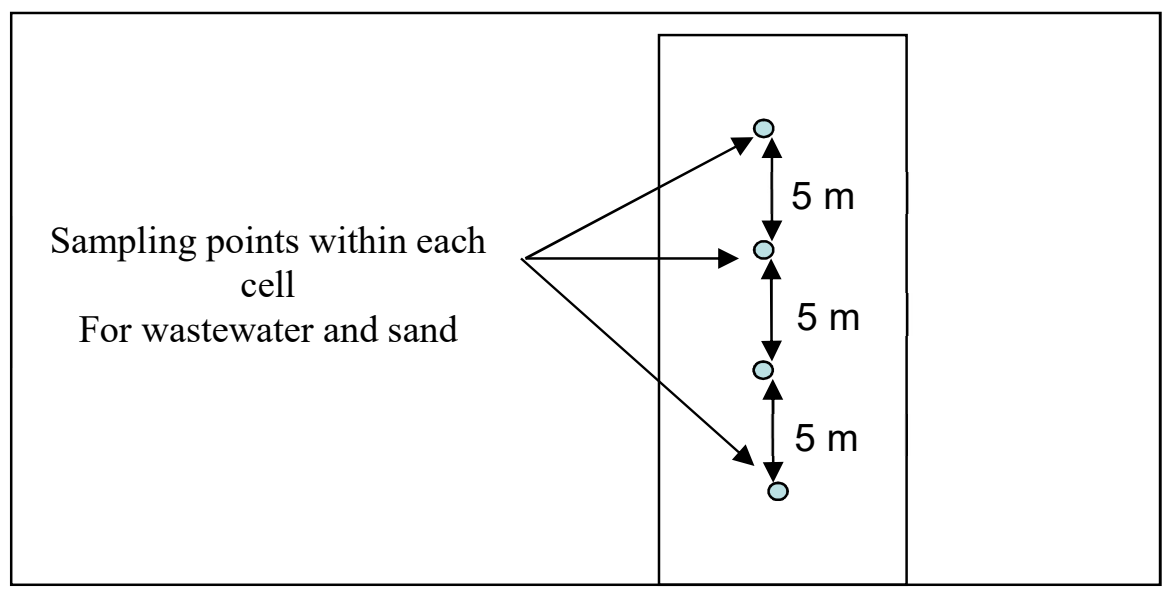

Figure 3: Sampling Points Within Each Cell of the CW

\section{Phosphorus Removal Performance}

The treatment performance of all the CW cells was evaluated and compared using both the influent and effluent $P$ concentrations, as well as the percentage of $\mathrm{P}$ removal. The percentage of phosphorus removed, was calculated according to Equation 2. 
Percentage of $\mathrm{P}$ removed $=\frac{\left(C_{i n}-C_{e}\right)}{C_{i n}} \times 100$

where $C_{i n}$ is the influent $P$ concentration $(\mathrm{mg} / \mathrm{l}), C_{e}$ is the effluent $\mathrm{P}$ concentration $(\mathrm{mg} / \mathrm{l})$

\section{RESULTS AND DISCUSSION}

\section{Dissolved Oxygen (DO) Values}

The results for DO are presented in Table 1 and Figure 4. The DO concentration values of the influent into the $\mathrm{CW}$, varied from 0.6 to $3.5 \mathrm{mg} / \mathrm{l}$ with a mean value of 0.75 $\pm 0.189 \mathrm{mg} / \mathrm{l}$.The range and mean effluent DO concentration values for different $\mathrm{CW}$ cells were as follows; Cell A $0.1-7.81 \mathrm{mg} / 1$, $(2.161 \pm 0.320 \mathrm{mg} / 1)$ Cell B $0.1-7.93 \mathrm{mg} / 1$, $(2.261 \pm 0.448 \mathrm{mg} / \mathrm{l})$, Cell C $0.2-8.2 \mathrm{mg} / 1$ $(2.602 \pm 0.473 \mathrm{mg} / \mathrm{l})$ and Cell D 0.2 $7.24 \mathrm{mg} / 1(2.106 \pm 0.347 \mathrm{mg} / \mathrm{l})$. The low DO concentration in the septic tank, can be attributed probably due to the fact that there are anaerobic bacterial processes taking place in it_Sousa et al., 2001). These processes deplete the levels of DO. As the wastewater is treated in the $\mathrm{CW}$, there is a noticeable trend of DO increase. This DO value increase can be attributed to aeration enhanced by plants in the $\mathrm{CW}$, which might have effected aeration in the substrate and subsequently the wastewater (Vymazal., 1998; Garcia et al., 2010). Also the increase in $\mathrm{DO}$ in the $\mathrm{CW}$, can be due to photosynthesis brought about by the CW plants. Agnieszka (2004) found that plants contribute to $\mathrm{P}$ removal, by improving the $\mathrm{P}$ holding capacity of sediments by the release of oxygen from the plant roots. Lavrova and Koumanova, (2006), revealed that rooted plants actively transport oxygen from the atmosphere to the media. Some oxygen leaks from the root hairs into the rhizosphere, thus supporting aerobic microorganisms. This contributes to higher DO concentrations in the planted cells. Figure 4 shows the mean DO concentration values in each $\mathrm{CW}$ cell. It can be noted that cells which contained sand and Cyperus Papyrus had the highest DO concentration.

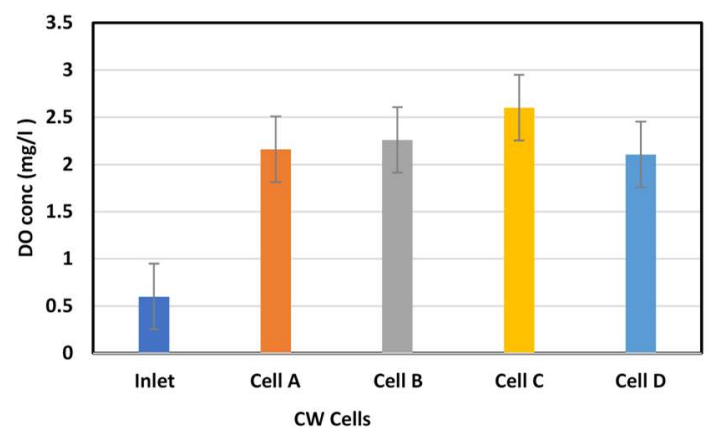

Figure 4: Mean Dissolved Oxygen (DO) Concentration Values in the CW Cells pH Values

$\mathrm{pH}$ is one of the parameters that influence the removal of phosphorus by controlling various biochemical processes taking place in the CWs (Garcia et al., 2010). Table 1 and Figure 5 show that $\mathrm{pH}$ vales ranged from 5.82 - 7.73, 7.03 - 7.91, 6.4 - 8.00, $6.36-8.1$ and $6.09-7.91$ with mean value of $7.10 \pm 0.090,7.45 \pm 0.050,7.27 \pm 0.080$, $7.33 \pm 0.080$ and $7.27 \pm 0.090$ for inlet and effluent of Cell A, Cell B, Cell C and Cell $\mathrm{D}$ respectively. From Figure 5, it is observed from the results that $\mathrm{pH}$ increases from the inlets to the outlets of the $\mathrm{CW}$ cells. The $\mathrm{pH}$ increase could be attributed to the increase in alkalinity as the wastewater gets treated in the CW cells. This is probably due to the oxidation of part of the volatile fatty acids and ammonification of the organic nitrogen as reported by (Sousa et al., 2001).

Lavrova and Koumanova, (2006) observed that during photosynthesis processes, plants consume carbon dioxide and release oxygen. Submerged aquatic plants growing within the water column, raise DO levels in the CW water and deplete the dissolved carbon dioxide. This results into increased $\mathrm{pH}$ values. Figure 5 shows the mean influent and effluent $\mathrm{pH}$ values of the $\mathrm{CW}$ cells. The $\mathrm{pH}$ values were within the recommended range of $4.0<\mathrm{pH}<9.5$ for the existence of many wastewater treatment bacteria (Mann, 1996). 


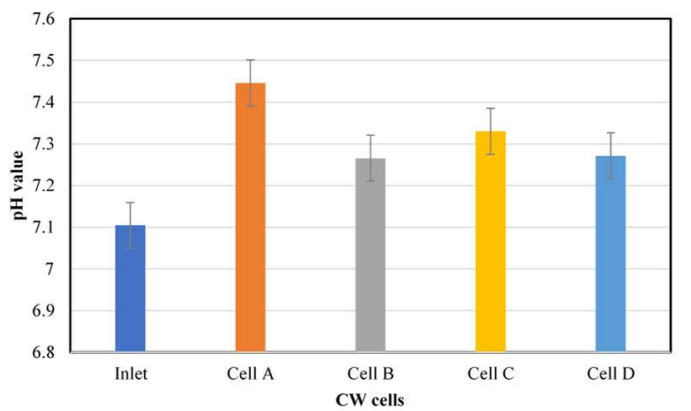

Figure 5: Mean pH Values from $\mathrm{CW}$ cells

The increase in $\mathrm{pH}$ can also be attributed to the mineralogical composition of the substrate material used in the CW. If the substrate material is of the limestone origin, then there is that possibilty of increase in alkalinity of the wastewater. The control cell $\mathrm{A}$, with sand only, had the highest $\mathrm{pH}$ increase. This is probably due to the fact that where there are no plants, more ammonification of organic nitrogen takes place, whereas in the planted cells some of the nitrogen is taken up by the plants. Sousa et al., (2001) reported that the ammonification of organic nitrogen in CWs results in increase in alkalinity i.e. high $\mathrm{pH}$ values.

\section{Temperature Values}

Findings for temperature variation are presented in Table 1 and Figure 6 . Temperature varied from Temperature values ranged from $22.7^{\circ} \mathrm{C}-29.3^{\circ} \mathrm{C}$, $22.4^{\circ} \mathrm{C}-28.9^{\circ} \mathrm{C}, 22.1^{\circ} \mathrm{C}-28.2^{\circ} \mathrm{C}, 22.4^{\circ} \mathrm{C}-$ $28.1^{\circ} \mathrm{C}$ and $22^{\circ} \mathrm{C}-28^{\circ} \mathrm{C}$ with mean value of $27.16 \pm 0.401^{\circ} \mathrm{C}, 26.30 \pm 0.387^{\circ} \mathrm{C}, 26.14 \pm$ $0.357^{\circ} \mathrm{C}, 26.01 \pm 0.349^{\circ} \mathrm{C}$ and $26.03 \pm$ $0.359^{\circ} \mathrm{C}$ for inlet and effluent of Cell A, Cell B, Cell C and Cell D respectively. Figure 6 shows that the results from the study shows that, there is a decreasing trend in wastewater temperature from the influent to the effluent. This can be due to the cooling effects brought about by the shading effects of the plants, as the wastewater moves through the $\mathrm{CW}$ cells. Wastewater cools as it moves through the sand which is under the shade of the plants. Also, it could be due to diurnal air temperature variation (Brix, 1997; Vymazal et al., 1998). Table 1. below presents the summary of the physico-chemical parameters results from this work.

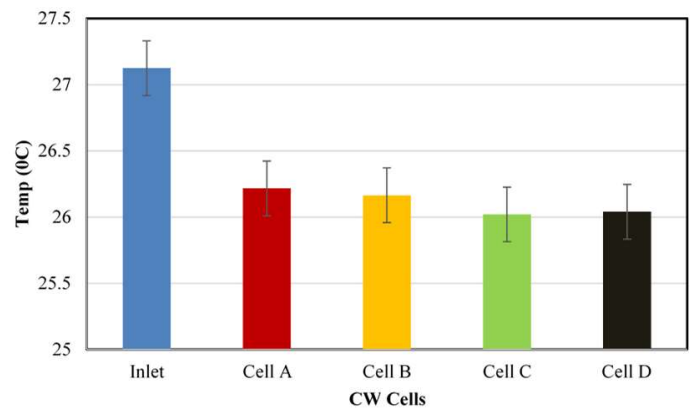

Figure 6: Mean Temperature Values in the $\mathrm{CW}$ cells

Table 1: Summary of the Physico-Chemical Parameters Measured in the CW, $(n=25)$

\begin{tabular}{|c|c|c|c|c|c|c|c|c|c|}
\hline \multirow[b]{2}{*}{$\begin{array}{l}\text { Samplin } \\
\text { g Point }\end{array}$} & \multicolumn{3}{|c|}{ DO (mg/l) } & \multicolumn{3}{|l|}{ pH } & \multicolumn{3}{|c|}{ Temperature $\left({ }^{\circ} \mathbf{C}\right)$} \\
\hline & Range & Mean & $\begin{array}{l}\text { Std } \\
\text { Dev }\end{array}$ & Range & Mean & $\begin{array}{l}\text { Std } \\
\text { Dev }\end{array}$ & $\begin{array}{l}\text { Rang } \\
\text { e }\end{array}$ & $\begin{array}{l}\text { Mea } \\
\text { n }\end{array}$ & $\begin{array}{l}\text { Std } \\
\text { Dev }\end{array}$ \\
\hline Inlet & $0.6-3.5$ & 0.601 & 0.189 & $5.82-7.73$ & 7.10 & 0.090 & $\begin{array}{l}22.7- \\
29.3 \\
\end{array}$ & 27.16 & 0.401 \\
\hline $\begin{array}{l}\text { Cell A } \\
\text { Effluent }\end{array}$ & $0.1-7.81$ & 2.161 & 0.320 & $7.03-7.91$ & 7.45 & 0.050 & $\begin{array}{l}22.4- \\
28.9 \\
\end{array}$ & 26.30 & 0.387 \\
\hline $\begin{array}{l}\text { Cell B } \\
\text { Effluent }\end{array}$ & $0.1-7.93$ & 2.261 & 0.448 & $6.4-8.00$ & 7.27 & 0.080 & $\begin{array}{l}22.1- \\
28.2\end{array}$ & 26.14 & 0.357 \\
\hline $\begin{array}{l}\text { Cell C } \\
\text { Effluent }\end{array}$ & $0.2-8.2$ & 2.602 & 0.473 & $6.36-8.10$ & 7.33 & 0.080 & $\begin{array}{l}22.4- \\
28.1\end{array}$ & 26.01 & 0.349 \\
\hline $\begin{array}{l}\text { Cell D } \\
\text { Effluent }\end{array}$ & $0.2-7.24$ & 2.106 & 0.347 & $6.09-7.91$ & 7.27 & 0.090 & $\begin{array}{ll}22 & - \\
28 & \end{array}$ & 26.03 & 0.359 \\
\hline
\end{tabular}

$\mathrm{n}=$ number of samples

Std Dev $=$ Standard Deviation 


\section{Phosphorus Removal Efficiency}

In this study, phosphorus (as $\mathrm{PO}_{4}{ }^{3-}$ ) was determined since it is the main focus of the study. Equation 2 was used to determine the percentage of $\mathrm{P}$ removed. This represented the efficiency of the $\mathrm{CW}$ in the removal of phosphorus. Table 2 shows the results that were obtained in the $\mathrm{CW}$ cells. It has been found that the mean $\mathrm{P}$ concentration value at the inlet was $9.83 \mathrm{mg} / \mathrm{l}$. The mean $\mathrm{P}$ concentration values at the outlets were $0.630 \mathrm{mg} / 1,0.258 \mathrm{mg} / \mathrm{l}, 0.188 \mathrm{mg} / \mathrm{l}$ and $0.157 \mathrm{mg} / 1$ for the CW cells A, B, C and D respectively.

Whereas Cell A had a removal efficiency of 93.59\%, Cell Bhad 97.37\% and Cell C

had $98.09 \%$. Cell D was found to have the highest treatment efficiency of $98.40 \%$.
This could be probably due to the high productivity rate as well as high $\mathrm{P}$ uptake rate of Phragmites Mauritianus due to their physiology. Hence, the removal efficiency for the control Cell A was not as high as compared to the other cells that were planted. This is mainly due to the fact that, the mechanisms of $\mathrm{P}$ removal in a $\mathrm{CW}$ involves phosphates uptake by plants (Hill et al., 2000; Garcia et al., 2010; Walter and Kadlec, 2011). Since the control cell was not planted, it was bound to have the lowest $P$ removal efficiency and especially if the sand was not composed of $\mathrm{Al}$ and $\mathrm{Ca}$ elements (Agnieszka, 2004; Ballantine et al., 2010).

Table 2: Summary of Phosphorus concentrations and Removal Efficiencies

\begin{tabular}{|l|l|l|l|l|}
\hline & \multicolumn{2}{|l|}{ P Concentrations Values (mg/l) } & \\
\hline & \multicolumn{2}{|l|}{} & & $\begin{array}{l}\% \\
\text { (Removal } \\
\text { Sample }\end{array}$ \\
& Range & Mean & Std Dev & Eficiency) \\
\hline Inlet & $0-20.49$ & 9.828 & 5.635 & \\
\hline Cell A Effluent & $0-2$ & 0.630 & 0.630 & 93.59 \\
\hline Cell B Effluent & $0-0.7$ & 0.258 & 0.208 & 97.37 \\
\hline Cell C Effluent & $0-0.5$ & 0.188 & 0.133 & 98.09 \\
\hline Cell D Effluent & $0-1.2$ & 0.157 & 0.249 & 98.40 \\
\hline
\end{tabular}

Std. Dev. $=$ Standard Deviation

In Cell A, P removal is dependent upon adsorption and microbial uptake processes only, hence a lower efficiency in P removal (Vyamazal et al., 1998b; Garcia et al., 2010). Interestingly, cells that were planted exhibited only slight differences in $\mathrm{P}$ removal efficiencies. Cell D was observed to be the most effective in removing $\mathrm{P}$ as compared to the other cells. Cell D was then followed by cell C planted with Cyperus Papyrus and lastly cell B with Typha Latifolia.

Statistical analyses showed that there was no statistically significant difference $(p>0.05)$ in the $P$ removal efficiencies of cells planted with different species. Meng et $a l, .2014$ found no statistically significant difference in $\mathrm{P}$ removal efficiencies $(p>0.05)$ among the three systems with different plants species. Similar results were observed by Cui et al., 2011 who reported that the $\mathrm{P}$ removal efficiency was higher in planted cells than in control cell. About $66.3 \%$ of TP in the influent was removed in $\mathrm{CW}$ planted with $C$. Alternifolius whereas control cell removed about 55.0\%. Ballantine and Tanner 2010 found that sand adsorption to be a major $\mathrm{P}$ removal mechanism.

However, Agnieszka, 2004 revealed that the main $\mathrm{P}$ removal mechanisms in the $\mathrm{CW}$ was $\mathrm{CW}$ plant uptake. The main $\mathrm{P}$ removal 
mechanism differences could be probably due to the fact that, plant growing media, i.e sand used in this work, were not composed of $\mathrm{Ca}$ and $\mathrm{Al}$ elements. These elements are essential in $\mathrm{P}$ removal. Similar finding was observed and reported by Ballantine et al., (2010).

A study by Okurut, 2000 in Uganda, revealed that, nitrogen and phosphorus removal via plant uptake is only significant at the exponential growth phase of plants. This is more so in Phragmites Mauritianus, which had nearly $90 \%$ of its total biomass above ground. This is also make the
Phragmites Mauritianus to have the highest performance in this study, since the data used were just after the establishment of the $\mathrm{CW}$ which was one year within the its operation. At this stage, the plants were in the exponential growth phase too. Figure 7 shows the mean values of $P$ concentration in the $\mathrm{CW}$ effluents, as compared to the Botswana Bureau of Standards (BOBS) effluent discharge standards (BOS 93:2005) of $0.5 \mathrm{mg} / 1$ for phosphorus, before discharging wastewater into the environment (BOBS, 2005).

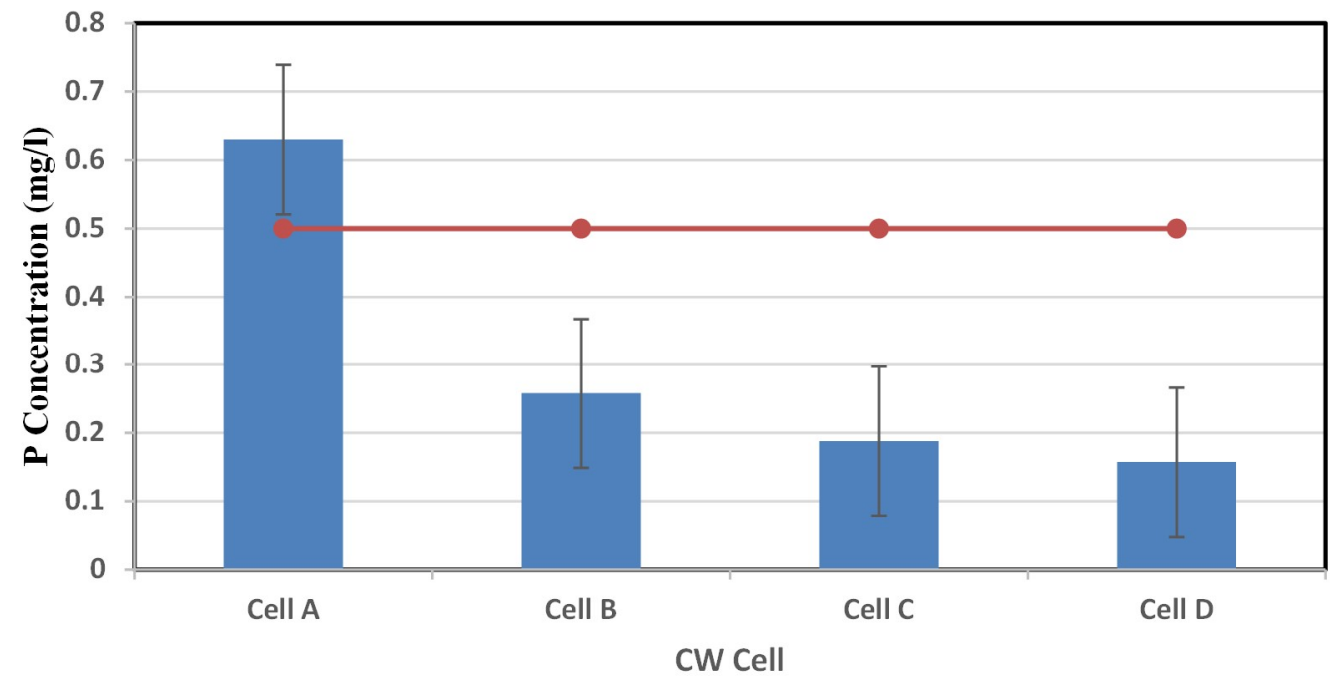

\section{Figure 7: Mean $P$ concentration Values in Effluent against the BOBS Discharge Standard}

All the mean values of $\mathrm{P}$ concentration in all the effluents complied with the BOBS standard except for cell A. Since all the cells effluents mixed when they got into the collection chamber, the mean concentration attained in the chamber was $0.31 \mathrm{mg} / \mathrm{l}$ which is still lower than the BOBS standard. The effluents can therefore be safely reused for irrigation.

\section{Phosphorus Removal Along the CW Cells}

During data collection, wastewater samples were also taken within each cell at intervals of $5 \mathrm{~m}$ from the inlet as described in Design and Operation of CW cells sub-section. The results are as shown in Figure 8. The results show that, $\mathrm{P}$ is removed at different concentrations in each cell. The $\mathrm{P}$ removal exhibits the first order reaction rate as wastewater moves through the substrata (Hill et al., 2000; Garcia et al., 2010; Walter and Kadlec, 2011). In cells A and B, P is removed at higher rates compared to the other cells. This suggests that, the longer, the wastewater takes flowing through the lengthy cell, the more hydraulic retention time is attained to facilitate maximum $P$ removal and overall wastewater treatment (Vymazalet al., 1998, Hill et al., 2000). However, this needs more land for the construction of the CWs which can be costly to acquire in some places. The results for $\mathrm{P}$ removal in this study, are in line with 
findings reported from other studies (Walker, 1995, Kadlec and Walker,1999; Kadlec and Wallace 2009). Walker, (1995) and Kadlec and Walker (1999) found that, as water with elevated $\mathrm{P}$ concentration moves through a wetland ecosystem, $\mathrm{P}$ is removed and a gradient of decreasing $\mathrm{P}$ concentration is produced along the flow path. Interestingly, Walkerand Kadlec, 2011 observed that the water column $\mathrm{P}$ gradient, is typically accompanied by gradients of $\mathrm{P}$ storage in plants and soils.

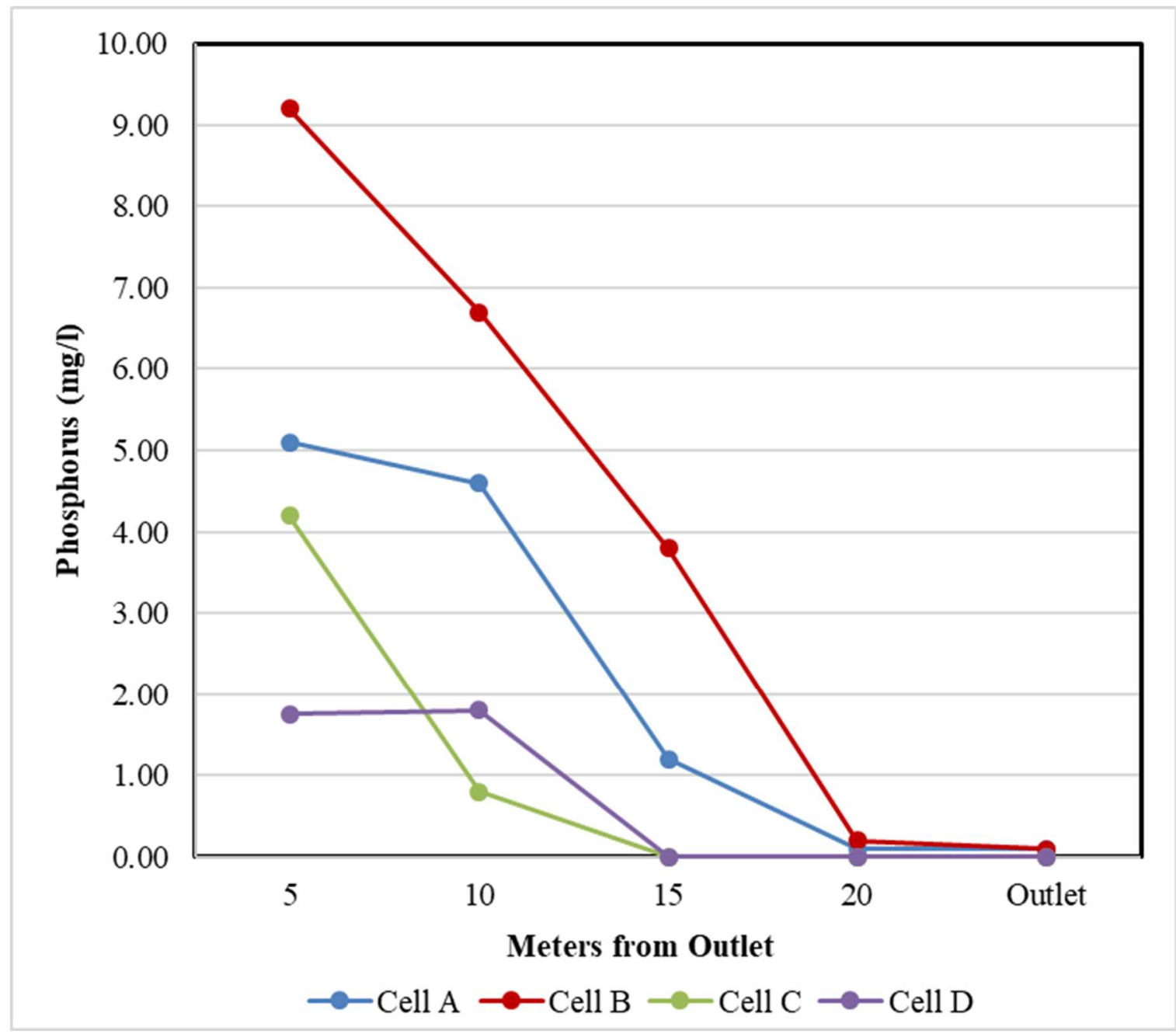

Figure 8: Phosphorus removal along the CW Cells

\section{CONCLUSION AND}

\section{RECOMMENDATIONS}

This study was carried out in order to determine the performance of the DWA $\mathrm{CW}$ in removing $\mathrm{P}$ from domestic wastewater. The main thrust was to determine the effects of different $\mathrm{CW}$ plants, i.e. capacities and efficiencies in $\mathrm{P}$ removal. It was also intended to determine the most effective type of plants for the $\mathrm{P}$ removal from domestic wastewater. This study has demonstrated that $\mathrm{CW}$ plants have effects on $\mathrm{P}$ removal from domestic wastewater. Different plant spices have different $\mathrm{P}$ removal efficiencies. Phragmites Mauritius has been found to have the highest $\mathrm{P}$ removal efficiencies for domestic wastewater. Further, it has been proven that plants contribute to high $\mathrm{P}$ removal. Sand alone is not effective in $\mathrm{P}$ removal. Despite the fact that $\mathrm{CW}$ plants contributed towards phosphorus removal 
from domestic wastewater, there was however no statistically significant performance difference $(p>0.05)$ in $P$ removal between the $\mathrm{CW}$ cells planted with different plant species. Out of three studied plant species, anyone of these species can be used as $\mathrm{CW}$ plant species depending on the availability and affordability. Further the mean effluent $\mathrm{P}$ concentrations from the different CW cells were; C1 $0.62 \mathrm{mg} / \mathrm{l}, \mathrm{C} 2$ $0.28 \mathrm{mg} / \mathrm{l}, \mathrm{C} 30.19 \mathrm{mg} / \mathrm{l}$ and C4 $0.16 \mathrm{mg} / \mathrm{l}$. Thus, the mean $\mathrm{P}$ concentration from the effluent of $\mathrm{C} 1$ was above the Botswana Bureau of Standards Limits of $0.5 \mathrm{mg} / \mathrm{l}$. Hence the effluent was non-compliant with Botswana standards for the discharge of effluent into the environment. On the other hand, since $\mathrm{CW}$ technology was piloted to assessment its domestic wastewater treatment feasibility, CWs are recommended to be an alternative, appropriate and adequate wastewater treatment technology for phosphorus removal. It can thus be adopted for domestic wastewater treatment for $P$ removal in Botswana. The study recommends that for the highest $\mathrm{P}$ removal efficiencies, Phragmites Mauritius should be selected as the most appropriate and effective plant species. CW plan selection guidelines should be developed to guide the $\mathrm{CW}$ designers on the most effective $\mathrm{CW}$ plants for $\mathrm{P}$ removal from domestic wastewater.

\section{ACKNOWLEDGEMENTS}

The authors would like to thank WaterNet for funding this study through the Master Programme in Integrated Water Resources Management (MIWRM) in the Department of Water Resources Engineering at the University of Dar es Salaam.

\section{REFERENCES}

Agnieszka K. A. (2004). Phosphorus removal from domestic wastewater in horizontal subsurface flow constructed wetland after 8 years of operation - a case study, Journal of Environmental Engineering and Landscape Management, 12(4): 126-131: https://doi.org/10.1080/16486897.2004. 9636833

Allan J. D. (2004). Landscapes and Rivers capes: The Influence of Land Use on Stream Ecosystems. Annual Review of Ecology, Evolution, and Systematics, 35: 257-284. http://dx.doi.org/10.1146/annurev.ecols ys.35.120202.110122

APHA. (2000). Standard methods for Examination of Water and Wastewater. American Public Health association, American Water Works Association, Water Control Federation: Washington.

Babatunde A., Zhao Y., O'Neill M. and O'Sullivan. B. (2008). Constructed wetlands for environmental pollution control: A review of developments, research and practice in Ireland, Environment International 34(1):11626. DOI: $10.1016 /$ j.envint.2007.06.013

Ballantine D. J. and Tanner C. C. (2010). Substrate and filter materials to enhance phosphorus removal in constructed wetlands treating diffuse farm runoff: a review, New Zealand Journal of Agricultural Research, 53(1): 71-95, DOI: $10.1080 / 00288231003685843$

Botswana Bureau of Standards (BOBS), BOS 93:2004. (2005). Water Qualitywastewater- Physical, Microbiological Requirements Specification, Gaborone, Botswana

Brix H. (1997). Do Macrophytes Play a Role in Constructed Treatment Wetlands? Water Science and Technology 35(5):11-17 DOI: 10.1016/S0273-1223(97)00047-4

Comber S., Gardner M., Georges K., Blackwood,D. and Gilmour D.(2013). Domestic source of phosphorus to sewage treatment works, Environmental Technology 34(10):1349-1358, https://doi.org/10.1080/09593330.2012. 747003 
Crites R., DombeckG., Watson R. C. and Williams, C. R. (1997). Removal of metals and ammonia in constructed wetlands, Water Environment Research, 69(2): 132-135.

Cui L., Zhu X., Ouyang Y.,Chen Y. and Yang F. (2011). Total Phosphorus Removal from Domestic Wastewater With Cyperus Alternifolius In VerticalFlow Constructed Wetlands At The Microcosm Level, International Journal of Phytoremediation, (2011), 13:7, pp. 692-701,

DOI:10.1080/15226514.2010.525552

Dodds W. K. and Smith V. H. (2016). Nitrogen, phosphorus, and eutrophication in streams, Inland Waters, 6 (2): 155-164: DOI:10.5268/IW-6.2.909

Dodds W. K. and Welch E. B. (2000). Establishing nutrient criteria in streams. J N Am Benthol Soc, 19: 186-196. DOI: $10.2307 / 1468291$

Fisher T. Melack J. Grobbelaar J. and Howarth R. (1995). Nutrient limitation of phytoplankton and eutrophication of inland, estuarine and marine waters. Scope-Scientific Committee on Problems of the Environment, International Council of Scientific Unions, 54: 301-322

García J., Rousseau D.P.L., Morató J., Lesage E., Matamoros V. and Bayona J. M. (2010). Contaminant Removal Processes in Subsurface-Flow Constructed Wetlands: A Review, Critical Reviews in Environmental Science and Technology, 40(7): 561661,

DOI: 10.1080/10643380802471076

HaddisA., Van der BruggenB. and Smets I. (2020). Constructed wetlands as nature based solutions in removing organic pollutants from wastewater under irregular flow conditions in a tropical climate, Ecohydrology and Hydrobiology, 20(1): 38-47

Hill C.M., Duxbury J., Geohring L. and Peck T. (2000). Designing constructed wetlands to remove phosphorus from barnyard runoff: A comparison of four alternative substrates, Journal of Environmental Science \& Health Part A, 35:8, 1357-1375, DOI: $10.1080 / 10934520009377040$

Howarth R. and Paerl H. W. (2008).Coastal marine eutrophication: Control of both nitrogen and phosphorus is necessary, Proc Natl Acad Sci U S A. 2008 Dec 9; 105(49): E103. Published online 2008 Dec 4. doi: 10.1073/pnas.0807266106

Kadlec R. and Walker W.W. (1999). Management models to evaluate phosphorus impacts in wetlands, Chapter 27. In K.R. Reddy, G.A. O'Connor, and C.L. Schelske (Eds.), Phosphorus biogeochemistry in subtropical ecosystems 621-642. Boca Raton, FL: Lewis.

Kadlec R. H. (2005). Phosphorus Removal in Emergent Free Surface Wetlands, Journal of Environmental Science and Health, 40:(7), 1293-1306, DOI: $10.1081 /$ ESE-200055832

Kadlec R. H. and Wallace S. D. (2009). Treatment wetlands, $2^{\text {nd }}$ ed. $10,349-401$, Taylor and Francis Group, LLC, Broken Sound Parkway NW

Kadlec R. H. and Knight R.L. (1996). Treatment Wetlands. Lewis Publishers, Boca Raton, 893 p.

Kimwaga R. J., Mbwette T. S. A., Mashauri D.A., Katima J. H. and Jorgensen S.E. (2004). Use of coupled Dynamic Roughing Filters and subsurface horizontal flow constructed wetlands system as appropriate technology for upgrading WSP effluents in Tanzania. Physics and Chemistry of Earth, 29: 1243 - 1251

Langergraber G., Leroch K., Pressl A., Rohrhofer R. and Haberl R. (2008). A two-stage subsurface vertical flow constructed wetland for high-rate nitrogen removal. Water Sci Technol, 57 (12): 1881-1887. https://doi.org/10.2166/wst.2008.319

Lavrova S. and Koumanova B. (2006, 2007). Polishing of Aerobically Treated Wastewater in A Constructed Wetland 
System: Journal of the Chemical Technology and Metallurgy, 42 (2):195200.

Lewis W. and Wurtsbaugh W. (2008). Control of Lacustrine Phytoplankton by Nutrients: Erosion of the Phosphorus Paradigm: International Review of Hydrobiology 93: 446-465: DOI:10.1002/IROH.200811065

Makris K. C., Andra S. S. and Botsaris G. (2014): Pipe Scales and Biofilms in Drinking-Water Distribution Systems: Undermining Finished Water Quality, Critical Reviews in Environmental Science and Technology, 44 (13): 14771523 , https://doi.org/10.1080/10643389.2013. 790746

Mann, R.A. (1996). Phosphorus Removal by Constructed Wetlands: Substratum Adsorption. Ph D Thesis, Faculty of Science and Technology, University of Western Sydney (Hawkesbury).

Mayo A. W. and Bigambo T. (2005). Nitrogen transformation in horizontal subsurface flow constructed wetlands I: Model development, Physics and Chemistry of the Earth, 30: 11-16, 658667

Meng P., Hu W., Pei H., Hou Q. and Ji Y. (2014). Effect of different plant species on nutrient removal and rhizospheric microorganisms distribution in horizontal-flow constructed wetlands, Environmental Technology,35 (7): 808816.

DOI: 10.1080/09593330.2013.852626 DOI: 10.1080/09593330.2013.852626

Murray A. and Buckley C. (2010). Designing reuse-oriented sanitation infrastructure: the design for service planning approach. In: P. Drechsela, C.A. Scott, L. Raschid, M. Redwood, and A. Bahri, (eds). Wastewater irrigation and health: assessing and mitigating risks in low-income countries. London: Earthscan, pp. 303318.

Obarska-Pempkowiak

H.https://www.sciencedirect.com/science/articl
e/abs/pii/S0045653599001113 - ! and Klimkowska K. (1999). Distribution of nutrients and heavy metals in a constructed wetland system. Chemosphere, 39: 303-312: https://doi.org/10.1016/S00456535(99)00111-3

Okurut, T. O. (2000). A Pilot study on Municipal Wastewater Treatment Using a Constructed Wetland in Uganda, Wageningen University dissertation no. 2873. (2000).

Oliveira M. and Machado A. V. (2013). The role of phosphorus on eutrophication: a historical review and future perspectives, Environmental Technology Reviews, 2(1): pp. 117-127, DOI: $10.1080 / 21622515.2013 .861877$

Paerl H. (2009). Controlling Eutrophication Along the Freshwater-Marine Continuum: Dual Nutrient ( $\mathrm{N}$ and $\mathrm{P}$ ) Reductions Are Essential: Estuaries and Coasts 32(4):593-601: DOI: 10.1007/s12237-009-9158-8

Scott C. A. and Raschid-Sally L. (2012). The global commodification of wastewater: Water International, 37(2): 147-155,

DOI: 10.1080/02508060.2012.662727

Scott C. A., Faruqui N. I. and Raschid-Sally L. (Eds.). (2004). Wastewater use in irrigated agriculture: confronting the livelihood and environmental realities. Wallingford, UK: CABI Publishing; Colombo, Sri Lanka: International Water Management Institute (IWMI); Ottawa, Canada: International Development Research Centre (IDRC). $193 p$

Senzia M., Mashauri D.A. and Mayo A.W. (2003). Suitability of Constructed Wetlands and waste stabilization ponds in wastewater treatment: nitrogen transformation and removal, Phys. Chem. Earth, 28: 1117-1124

Sousa J.T., van Haandel A. C. and Guimarães A. A. (2001). Post-treatment of anaerobic effluents in constructed wetland systems: Water Sci Technol, 44(4):213-9 
Sterner R. W. (2008). On the Phosphorus Limitation Paradigm for Lakes: Int Rev Hydrobiol, 93: 433-445: https://doi.org/10.1002/iroh.200811068

Sundaravadivel M. and Vigneswaran S. (2001). Constructed Wetlands for Wastewater Treatment, Critical Reviews in Environmental Science and Technology, 31(4): 351-409, DOI: $10.1080 / 20016491089253$

Sundaravadivel M. and Vigneswaran S. (2001).Constructed Wetlands for Wastewater Treatment, Critical Reviews in Environmental Science and Technology, (2001), 31(4): 351-409, DOI: $10.1080 / 20016491089253$

Tanner C.C.(1996). Plants for constructed wetland treatment systems: a comparison of the growth and nutrient uptake of eight emergent species Ecological Engineering7(1): 59-83.

United Nations. (2015). Sustainable Development Goals: Available online at https://sdgs.un.org/goals/goal6: Retrieved on 9th June 2015

van derPeijlM. J.and Verhoeven J.T.A. (1999). A model of carbon, nitrogen and phosphorus dynamics and their interactions in river marginal wetlands:
Ecological Modelling,118: 95-130: https://doi.org/10.1016/S03043800(99)00014-9

Vymazal J., Brix H., Cooper P. F., Green M. B. and Haberl R. (Eds.). (1998). Constructed Wetlands for Wastewater Treatment in Europe. - Backhuys Publishers, Leiden, 366 pages. ISBN 90-73348-72-2.

https://doi.org/10.1002/iroh.199808305 17

Walker W. W. and Kadlec R. H. (2011). Modelling Phosphorus Dynamics in Everglades Wetlands and Storm water Treatment Areas, Critical Reviews in Environmental Science and Technology, 41:S1, 430-446, DOI: 10.1080/10643389.2010.531225

Walker W.W. (1995). Design basis for Everglades storm water treatment areas. Water Resources Bulletin, 31: 671-685. Walker W.W. and Kadlec R.H.(2011). Modelling Phosphorus Dynamics in Everglades Wetlands and Stormwater Treatment Areas, Critical Reviews in Environmental Science and Technology, 11(41), 430-446, DOI: $10.1080 / 10643389.2010 .531225$ 